\title{
Commercial and Noncommercial Peroxidases Activity under Ultrasound and Microwave Treatment: a Pretreatment to Improve Wastewater Treatment
}

\author{
Simone M. Golunski, ${ }^{a}$ Thamarys Scapini, ${ }^{a}$ Tatiani Andressa Modkovski, ${ }^{a}$ \\ Camila T. Marques, ${ }^{a}$ Aline F. Camargo, ${ }^{a}$ Karina Paula Preczeski, ${ }^{a}$ Camila Dalla Rosa,${ }^{a}$ \\ Daiane P. Baldissarelli, ${ }^{a}$ Jéssica Mulinari, ${ }^{a}$ Bruno Venturin, ${ }^{a}$ Gean D. L. P. Vargas, ${ }^{a}$ \\ Jaqueline G. Buffon, ${ }^{b}$ Altemir José Mossi ${ }^{a}$ and Helen Treichel ${ }^{*, a}$ \\ ${ }^{a}$ Universidade Federal da Fronteira Sul, Campus de Erechim, Rod. RS 135, km 72, \\ 99700-000 Erechim-RS, Brazil \\ ${ }^{b}$ Escola de Química e Alimentos, Universidade Federal de Rio Grande, \\ CP 474, 96201-900 Rio Grande-RS, Brazil
}

\begin{abstract}
This study aimed at evaluating the activity of peroxidases after ultrasound and microwave radiation exposure as an alternative to the wastewater treatment improvement. The results showed that after treatment with ultrasound using a power of $30 \%$ and a temperature of $55^{\circ} \mathrm{C}$ was obtained an increase in relative activity, $129.5 \%$ in the enzyme from rice bran, $147.9 \%$ in the enzyme from soybean meal and $102.4 \%$ in the enzyme from horseradish. Using microwave radiation, the highest relative activity $(107.4 \%)$ was observed for the peroxidase extracted from rice bran with 10 seconds of reaction time and a reaction temperature of about $50{ }^{\circ} \mathrm{C}$. The data obtained in this study suggest that the ultrasonic bath and microwave are adequate for conducting reactions catalyzed by peroxidases because it was possible to increase their activity during the performed tests. Preliminary tests of enzyme application showed that the highest color removal occurred using $3 \mathrm{~mL}$ of the enzyme extract from rice bran and $\mathrm{H}_{2} \mathrm{O}_{2}$ concentrations of $40 \mathrm{mg} \mathrm{L}^{-1}$. This condition resulted in a color removal of about $40 \%$.
\end{abstract}

Keywords: peroxidase activity, ultrasound, microwave radiation

\section{Introduction}

Enzymes have been used since antiquity in the form of animal or plant tissue extracts. Known as biocatalysts, they are employed in several industrial processes. Many enzymes, of microbial or plant origin, are used in the treatment of wastewater and industrial waste. ${ }^{1}$ Among the most studied for degradation purposes, there are oxidative enzymes such as the peroxidases.

Peroxidases (EC 1.11.1.X) catalyze the electron oxidation of a variety of oxidizable xenobiotics using hydrogen peroxide $\left(\mathrm{H}_{2} \mathrm{O}_{2}\right)$ as acceptor molecule. ${ }^{2-4}$ Its activity has been identified in plants, microorganisms and animals. Due to their oxidative nature, there are several areas where peroxidase could replace chemical oxidants used in current techniques. ${ }^{5}$ The most used chemical oxidants for this type of chemical treatment are oxidizers such as ozone, permanganate, peroxide, persulfate and others. ${ }^{6}$ It

*e-mail: helentreichel@gmail.com should be noted that the application of chemical oxidants may result in the formation of intermediate compounds formed from reactions between the chloride ions present in the sample to be treated and organic molecules, and the decomposition of these chlorinated by-products can lead to the formation of degradation products such as chlorophenol, chlorobenzene, chlorobenzoate, or various chlorinated products, ${ }^{6,7}$ which have the carcinogenic potential and bioaccumulate in nature. ${ }^{6}$

Furthermore, these enzymes can be extracted from rice bran and soybean meal, which are agroindustrial by-products, economically enabling the process. For this, there is a need for knowledge of the behavior of these biocatalysts in different reaction systems in order to evaluate their activity and conformational change, so they can be efficiently used in degradative processes.

The low frequency ultrasound has received increasing attention over the past decade for the improvement of several biotechnological processes. The use of an ultrasonic bath has advantages such as simplicity and low cost. The 
most apparent limitations are that the operating frequency is usually fixed and power variations can occur within the bath, therefore, the standardization of sampling sites is essential for comparative purposes. ${ }^{8}$

For years, ultrasound has been used in various applications of biotechnology, i.e., for the purpose of cell disruption to release intracellular enzymes and organelles that are applied in industry and in medicine. Other applications include the easy mass transfer from the cell to the solvent, the intensification of cellulose and pectinase transfer during the bioprocessing of cotton fabrics and during the oxidation of cholesterol to cholestenone by Rhodococcus erythropolis cells. The ultrasound appears to influence the reaction kinetics and reduce the time for esterification reactions. ${ }^{9}$

It is also being developed studies on the use of microwaves, in order to improve the performance of enzymes in reactions on a wide range of applications in different areas. The microwaves generate heat inside the reaction system, facilitating mass and heat transfer operations by accelerating the occurrence of certain reactions, including those catalyzed by enzymes. The advantages of using this reaction system are the low cost and that it is considered a clean method. The effects of microwaves in chemical reactions are related with the short-range molecular friction due to the continuous polarization of molecules caused by microwave irradiation. ${ }^{10,11}$

Microwaves favor the efficiency of molecular collisions due to the orientation of polar molecules involved in the reaction. These properties make the microwave irradiation an interesting tool for application in enzymatic processes, including the activation of peroxidases. ${ }^{11}$ In this context, the aim of this study is to evaluate the effect of ultrasound and microwave in the enzymatic activity of commercial and noncommercial peroxidases extracted from agro-industrial by-products aiming to improving wastewater treatment. The literature shows a lack of studies that evaluate the changes in terms of enzyme activity and stability after exposure to ultrasound and microwave irradiation. Specifically on peroxidases, no scientific study could be found, showing that this one is important for the area, since the enzymes under study may be applicable for different purposes, especially to improve wastewater treatment.

\section{Experimental}

\section{Raw material}

The rice bran and soybean meal samples were acquired in local agribusiness, packed in appropriate containers at the temperature of $4{ }^{\circ} \mathrm{C}$ until the extraction of peroxidase. Commercial peroxidases were acquired from SigmaAldrich (type VI, peroxidase obtained from horseradish).

\section{Enzyme extraction study}

The extraction of peroxidase was held from the agro-industrial by-products, rice bran and soybean meal. The initial conditions for enzyme extraction were based on the method described by Cardinali et al., ${ }^{12}$ where the extractor buffer media in a concentration of $5 \mathrm{mmol} \mathrm{L}^{-1}$ was added to the brans, followed by mechanical agitation during $60 \mathrm{~min}$ at room temperature, to breakage of cellular structure and protein solubilization. The crude enzyme extracts from the different experiments were centrifuged at $3220 \times \mathrm{g}$ for $10 \mathrm{~min}$ at a temperature of $4{ }^{\circ} \mathrm{C}$, and the supernatants were filtered to quantify the soluble protein and the specific peroxidase activity in each test.

\section{Evaluation of enzymes behavior in ultrasound}

The effects of ultrasound (Unique Inc., USC-1800A model, frequency US $40 \mathrm{kHz}$ and maximum power of $132 \mathrm{~W}, 0.42 \mathrm{~W} \mathrm{~cm}^{-2}$ ) temperature and power on the peroxidases activities were determined by an experimental design. To evaluate the effects of ultrasound on the enzymes activity, tests were performed in the presence and absence of ultrasound irradiation. A central composite design (CCRD) was conducted to evaluate the effects of temperature and power in the range of $30-80{ }^{\circ} \mathrm{C}$ and $0-60 \%$, respectively, as shown in Table 1 . The activity was determined according to the procedure described below. The exposure time of the enzymes in the conditions predetermined by the experimental design was determined by performing a kinetic in an ultrasound bath, and the time range corresponding to maximum enzyme activity was from 10 to $20 \mathrm{~min}$. The exposure time was fixed, in 10 minutes, in the conditions previously determined by experimental design. All results were analyzed using the Statistica 7.0 software (Statsoft Inc., Tulsa, OK, USA), considering a significance level of $95 \%(p<0.05)$.

\section{Evaluation of peroxidases behavior in microwave}

Samples of noncommercial peroxidases and type VI peroxidase obtained from horseradish were added in $5 \mathrm{mmol} \mathrm{L}^{-1}$ phosphate buffer ( $\mathrm{pH}$ 7.5). These samples were treated in microwave (Domestic, Eletrolux, controlled by power) for 5,10 and 15 seconds, where the equivalent temperatures were 25,50 and $70{ }^{\circ} \mathrm{C}$, respectively. 
Stability of the crude and precipitated enzymatic extract at low and high temperatures

The stability of all enzymatic extracts at low temperatures was studied at 4 and $-10{ }^{\circ} \mathrm{C}$ by measuring the activities each 5 days during storage. The evaluation of stability at high temperatures was carried out by incubation at 30, 45 and $60^{\circ} \mathrm{C}$. The activity was monitored every $24 \mathrm{~h}$ until total loss of activity. The enzyme activities were evaluated until 100 days of storage at all temperatures.

\section{Determination of enzymatic activity}

The determination of enzyme activity was performed according to Devaiah and Shetty method. ${ }^{13}$ The reaction medium was composed of $1 \mathrm{~mL}$ of the enzyme extract, $1.5 \mathrm{~mL}$ of phosphate buffer, $0.50 \mathrm{~mL}$ of guaiacol $0.08 \mathrm{~mol} \mathrm{~L}^{-1}$ and $1 \mathrm{~mL}$ of $\mathrm{H}_{2} \mathrm{O}_{2} 0.08 \mathrm{wt}$. \%, the absorbance of the oxidized compounds was obtained in spectrophotometer at $470 \mathrm{~nm}$. The enzymatic activity was estimated in terms of activity, through the oxidation reaction of the substrate to tetraguaiacol characterized by the orange color. One unit of peroxidase activity was defined as the protein mass that can cause an increase of 0.001 in absorbance unit per minute. ${ }^{14}$

\section{Treatment of textile synthetic effluent}

Aiming at evaluating a preliminary application of the enzymes in effluent treatment, $0.3 \mathrm{~g}$ of the enzymatic extract, treated using ultrasound systems, were weight and added to $10 \mathrm{~mL}$ of $\mathrm{pH} 7.5$ phosphate buffer $\left(5 \mathrm{mmol} \mathrm{L}{ }^{-1}\right)$.
The solubilized extract was subjected to the treatment of textile synthetic effluent.

The concentration of the textile synthetic effluent used was $100 \mathrm{mg} \mathrm{L}^{-1}$ of the dye 09-Red (Tingecor Guarany Ind. Com. Ltda) that presents the following composition: sodium chloride, a direct dye and dispersing in distilled water. The synthetic effluent sample $(0.1 \mathrm{~L})$ was exposed to treatment with both noncommercial enzymes, in an orbital shaker at $160 \mathrm{rpm}$. The samples were analyzed for the removal of color, using a spectrophotometer at $455 \mathrm{~nm}$. All analyzes were performed in triplicate.

\section{Results and Discussion}

\section{Evaluation of enzymatic activity in ultrasound}

The treatment with ultrasound was evaluated using a CCRD $2^{2}$, which matrix and respective results are shown in Table 1. Table 1 also shows the real and coded values of the independent variables (power and temperature) and the respective responses in terms of relative activity to the peroxidases extracted from rice bran ( $\mathrm{RB})$ and soybean meal (SM). Higher activities were obtained for the center point (129.5\%) and runs 2, 6 and 1 (128.6, 123.8 and $121.4 \%$, respectively) using $\mathrm{RB}$. We believe that the result obtained in the central point is interesting, since intermediate conditions, thinking about economic viability, resulted in a relevant activity increase. For the enzyme obtained from SM, the highest relative activity were $147.9 \% \mathrm{SM}$, using a temperature of $55^{\circ} \mathrm{C}$ and a power of $30 \%$. The central point for both answers showed little

Table 1. CCRD $2^{2}$ matrix (coded and real values) and respective results in terms of relative activity of the peroxidases

\begin{tabular}{|c|c|c|c|c|c|}
\hline Test & $\begin{array}{l}\text { Ultrasound } \\
\text { power / \% }\end{array}$ & Temperature $/{ }^{\circ} \mathrm{C}$ & $\begin{array}{c}\text { Relative activity } \\
\text { RB / } \%\end{array}$ & $\begin{array}{c}\text { Relative activity } \\
\text { SM / \% }\end{array}$ & $\begin{array}{c}\text { Relative activity } \\
\text { horseradish } \\
\text { peroxidase / \% }\end{array}$ \\
\hline Crude enzyme & - & - & 100.0 & 100.0 & 100.0 \\
\hline 1 & $-1(10)$ & $-1(37)$ & 121.4 & 121.4 & 99.5 \\
\hline 2 & $1(50)$ & $-1(37)$ & 128.6 & 124.3 & 99.3 \\
\hline 3 & $-1(10)$ & $1(73)$ & 11.9 & 124.3 & 99.7 \\
\hline 4 & $1(50)$ & $1(73)$ & 7.1 & 111.6 & 99.5 \\
\hline 5 & $-1.41(0)$ & $0(55)$ & 71.4 & 135.9 & 101.2 \\
\hline 6 & $1.41(60)$ & $0(55)$ & 123.8 & 121.4 & 102.8 \\
\hline 7 & $0(30)$ & $-1.41(30)$ & 114.3 & 142.7 & 101.5 \\
\hline 8 & $0(30)$ & $1.41(80)$ & 2.4 & 107.8 & 99.1 \\
\hline 9 & $0(30)$ & $0(55)$ & 126.7 & 146.6 & 102.8 \\
\hline 10 & $0(30)$ & $0(55)$ & 126.2 & 148.5 & 101.2 \\
\hline 11 & $0(30)$ & $0(55)$ & 135.7 & 148.5 & 103.2 \\
\hline
\end{tabular}

anitial activity $\mathrm{RB}$ peroxidase $=440.0 \mathrm{U} \mathrm{mL}^{-1} ; \mathrm{SM}$ peroxidase $=740.0 \mathrm{U} \mathrm{mL}^{-1}$; horseradish peroxidase $=539.7 \mathrm{U} \mathrm{mL}^{-1}$; $\mathrm{RB}_{\text {: rice bran; }} \mathrm{SM}$ : soybean meal. 
variation, indicating good reproducibility of the process. For the peroxidase extracted from RB, the smaller relative activities were found in tests $8(2.4 \%)$ followed by test 4 $(7.1 \%)$ and test $3(11.9 \%)$. These results are possibly due to the high temperatures used during the execution of these tests, causing the enzyme denaturation. However, for the peroxidase extracted from SM no significant variations in the relative activity of the enzyme occurred, when compared with the one from RB.

Data presented in Table 1 were statistically treated and it was possible to obtain empirical models presented in Table 2. These models describe the behavior of the noncommercial enzymes after treatment.

Analysis of variance was used to validate these models and as calculated $\mathrm{F}$ was higher than listed one, we built the response surfaces presented at Figure 1. Considering the results obtained for the commercial enzyme, the coded model was not validated, so we presented the Pareto chart of effects (Figure 2) that presents the effects of the evaluated parameters on the enzymatic activity. One can see that the studied variables did not influence the enzyme activity in this case.

From these results it was observed that the behavior of the enzymatic activity of peroxidase is modified when treated with ultrasound. The relative activities obtained showed that average conditions of temperature $\left(50{ }^{\circ} \mathrm{C}\right)$ and power $(30 \%)$ generate the best results.

The observed behavior in relation to temperature is partially explained in the study of Wang et al. ${ }^{15}$ which stated that the sonication of a liquid causes two main effects, cavitation and heating. The shear stress caused by collapsing bubbles may slightly promote a heating that is not measured due to the sensor position, which can result in a local temperature increase, which results in less pronounced effects of temperature on the enzyme activity in the presence of ultrasound.

It can be noticed a gap in the literature regarding the use of ultrasound to increase peroxidase activity, but the results of this study are similar to those found for other enzymes, such as Souza et al. ${ }^{16}$ who evaluated the commercial enzyme amylase activity under the irradiation of ultrasound. For this, they used a design of experiments to evaluate the exposure temperature and $\mathrm{pH}$ in relation to enzymatic activity in the presence and absence of ultrasonic irradiation. Results showed that ultrasound changed the
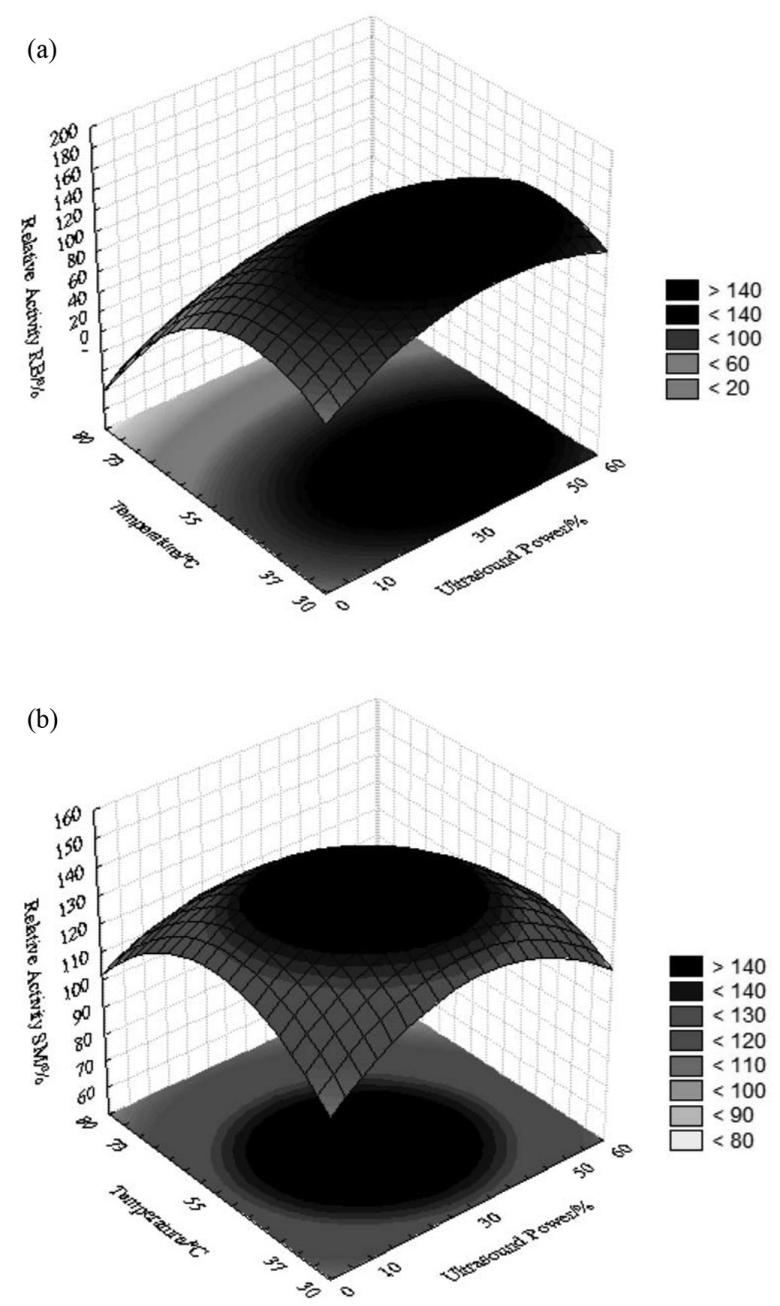

Figure 1. Response surfaces showing the behavior of peroxidases from (a) RB and (b) SM after treatment in ultrasound.

enzyme behavior, because it showed superior activity compared with the absence of ultrasound.

\section{Evaluation of enzymatic activity in microwave}

The results obtained from the treatment performed with microwaves in order to activate the commercial and noncommercial peroxidases are shown in Table 3. The highest relative activity $(p<0.05)$ was observed in test 2 (107.5\%) for the peroxidase extracted from RB with 10 seconds of reaction time and a reaction temperature of about $50^{\circ} \mathrm{C}$.

Table 2. Coded empirical models obtained for noncommercial enzymes from rice bran and soybean meal

\begin{tabular}{lc}
\hline Enzyme source & Enzyme activity $/ \%$ \\
\hline RB & $126.3+9.5 \times \mathrm{P}-17.0 \times \mathrm{P}^{2}-48.7 \times \mathrm{T}-36.8 \times \mathrm{T}^{2}-2.9 \times \mathrm{P} \times \mathrm{T}$ \\
$\mathrm{SM}$ & $147.9-3.9 \times \mathrm{P}-11.3 \times \mathrm{P}^{2}-7.4 \times \mathrm{T}-13.0 \times \mathrm{T}^{2}-3.9 \times \mathrm{P} \times \mathrm{T}$ \\
\hline
\end{tabular}

P: ultrasound power; T: temperature used in the treatment; RB: rice bran; SM: soybean meal. 
Table 3. Residual activities of commercial and noncommercial peroxidases treated in microwave

\begin{tabular}{lcccc}
\hline Test & time / s & Rice bran relative activity / \% & Soybean meal relative activity $/ \%$ & Horseradish relative activity $/ \%^{\mathrm{a}} \%$ \\
\hline 1 & 5 & $95.1^{\mathrm{b}} \pm 1.0$ & $96.4^{\mathrm{a}} \pm 1.1$ & $82.9^{\mathrm{a}} \pm 0.5$ \\
2 & 10 & $107.5^{\mathrm{a}} \pm 1.1$ & $94.7^{\mathrm{a}, \mathrm{b}} \pm 1.1$ & $81.1^{\mathrm{a}, \mathrm{b}} \pm 0.4$ \\
3 & 15 & $26.4^{\mathrm{c}} \pm 2.1$ & $91.0^{\mathrm{b}} \pm 2.7$ & $80.6^{\mathrm{a}} \pm 0.9$ \\
\hline
\end{tabular}

${ }^{a}$ Different letters in the same column represent a significant difference at $95 \%(p<0.05$, Tukey's test $)$; initial activity RB peroxidase $=440 \mathrm{U} \mathrm{mL}^{-1}$; initial activity SM peroxidase $=740 \mathrm{U} \mathrm{mL}^{-1}$; initial activity horseradish peroxidase $=540 \mathrm{U} \mathrm{mL}^{-1}$.

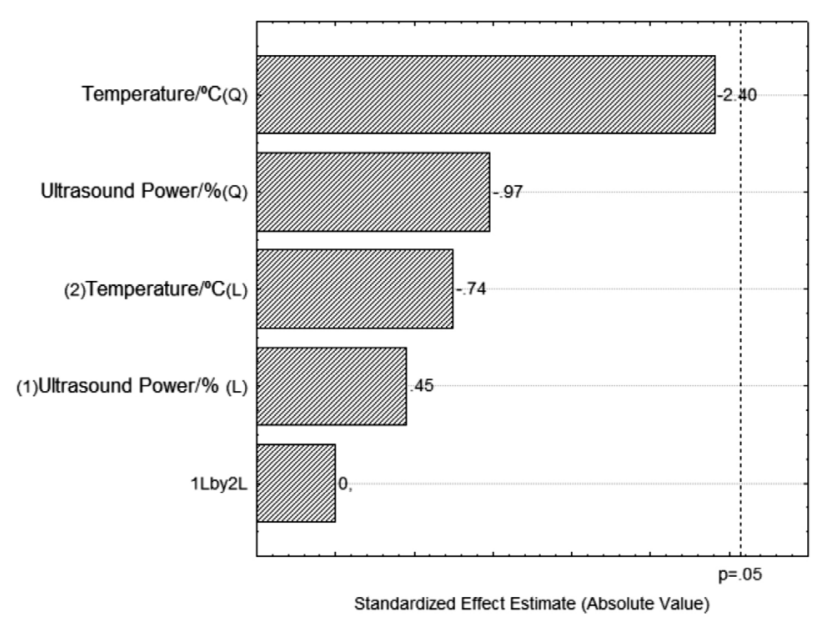

Figure 2. Pareto chart of effects for the horseradish relative activity (\%) after treatment in ultrasound.

Other authors also note activation of vegetable peroxidase after heat treatment. Ciou et al. ${ }^{17}$ studied the effect of heat on the peroxidase activity from water chestnut pericarp (Trapa Taiwanensis Nakai). Peroxidase activity, originally of 38 units $\mathrm{g}^{-1}$ of sample, increased slightly in pericarp samples that were heated from 30 to $40{ }^{\circ} \mathrm{C}$ for 10-60 min. Furthermore, the peroxidase activity rapidly increased when the samples were treated at $50-60{ }^{\circ} \mathrm{C}$ for $10-60 \mathrm{~min}$. The greater peroxidase activity was at $60{ }^{\circ} \mathrm{C}$ with 30 minutes of heat treatment. The peroxidase in this vegetable was almost completely inactivated when the temperature was increased to $100{ }^{\circ} \mathrm{C}$ in $10 \mathrm{~min}$.

Lopes et al. ${ }^{11}$ suggested that in the temperatures of 30 and $45^{\circ} \mathrm{C}$, interactions in the native state are maximized, keeping in the same values the angles of twist and of the polypeptide chains and low entropy, explaining the self activation of the enzyme.

As can be seen in Table 3, treatment with microwave possibly caused enzyme conformational changes, according to Lopes et al. ${ }^{11}$ Small changes in the secondary structure of the enzyme at low temperatures $\left(30-45^{\circ} \mathrm{C}\right)$ have activation effect, whereas at highest temperatures the effect on the enzyme is deleterious on its activity, as can be observed in the test 3 for the enzyme extracted from rice bran. The comparison of the obtained results with the literature was not possible because, currently, this type of system is only used for enzyme inactivation of the enzyme, what makes this work a promising technology for increasing the enzyme activity.

Stability of the crude and precipitated enzymatic extracts to low and high temperatures

After 160 hours of incubation at $30^{\circ} \mathrm{C}$, almost complete deactivation of all enzymes occurred. At $45^{\circ} \mathrm{C}$ the enzymes did not present an initial activation, but this extracts kept the enzyme activity until 116 hours of incubation. At $60^{\circ} \mathrm{C}$, all extracts lost the activity during the incubation time (92 hours) and the commercial enzyme, pretreated using ultrasound, was the most heat sensitive (loss of all activity after 44 hours of incubation).

The evaluation of low temperature stability showed that the enzymes presented higher stabilities. All of them kept $100 \%$ of their activity until 60 days of storage at 4 and $-10{ }^{\circ} \mathrm{C}$.

\section{Treatment of textile synthetic effluent}

Preliminary tests of enzyme application showed that the higher color removal percentage occurred using $3 \mathrm{~mL}$ of the enzyme extract and $\mathrm{H}_{2} \mathrm{O}_{2}$ concentrations of $40 \mathrm{mg} \mathrm{L}^{-1}$. This condition resulted in a color removal of about $40 \%$ using peroxidases from rice bran. The enzymes extracted from SM were not efficient in the color removal, presenting results of about $5 \%$.

\section{Conclusions}

In this study, experimental data on the effects of ultrasound irradiation on the peroxidase activity extracted from RB and SM were presented. Ultrasound has changed the behavior of the enzyme activity of both peroxidases. The results of this study showed that after the treatment with ultrasound using a power of $30 \%$ and a temperature of $55{ }^{\circ} \mathrm{C}$ was obtained an increase in the relative activity of peroxidases (129.5\% RB and $147.9 \% \mathrm{SM}$ ). These results enable the definition of the operating ranges of the enzymes in terms of residual activity for later application 
of these as catalysts in reactions of interest. The usage of ultrasound proved to be a promising technology to be used in enzymatic reactions due to its positive effects on peroxidases activities. The study of the effects of treatment with microwaves in the enzymatic activity and its structure are essential for the viability of using this technique. The data obtained in this study suggest that the treatment with microwaves is a reaction medium for conducting reactions catalyzed by peroxidases because it was possible to increase their activity during the performed tests. Preliminary tests of enzyme application showed that the higher color removal percentage occurred using $3 \mathrm{~mL}$ of the enzymes extract and $\mathrm{H}_{2} \mathrm{O}_{2}$ concentrations of $40 \mathrm{mg} \mathrm{L}^{-1}$. This condition resulted in a color removal of about $40 \%$.

\section{Acknowledgments}

The authors thank CNPq, CAPES and FAPERGS for the financial support of this work and scholarships.

\section{References}

1. Bon, E. P. S.; Ferrara, M. A.; Corvo, M. L.; Interciencia 2008, 506.

2. Tekchandani, S.; Guruprasad, K. N.; Plant Sci. 1998, 136, 131.

3. Tafazoli, S.; O’brien, P. J.; Drug Discovery Today 2005, 10, 617.

4. Mathé, C.; Barre, A.; Jourda, C.; Dunand, C.; Arch. Biochem. Biophys. 2010, 500, 58.

5. Hamid, M.; Rehman, K.; Food Chem. 2009, 115, 1177.

6. Devi, P.; Das, U.; Ajay K.; Sci. Total Environ. 2016, 571, 643.

7. Yuan, R.; Ramjaun, S. N.; Wang, Z.; Liu, J.; J. Hazard. Mater. 2011, 196, 173.
8. Barton, S.; Bullock, C.; Weir, D.; Enzyme Microb. Technol. 1996, 18, 190.

9. Rokhina, E. V.; Lens, P.; Virkutyte, J.; Trends Biotechnol. 2009, 27, 298.

10. Herrero, M. A.; Kremsner, J. M.; Kappe, C. O.; J. Org. Chem. 2008, 73, 36 .

11. Lopes, L. C.; Barreto, M. T. M.; Gonalves, K. M.; Alvarez, H. M.; Heredia, M. F.; de Souza R. O. M. A.; Cordeiro, Y.; Dariva, C.; Fricksa, A. T.; Enzyme Microb. Technol. 2015, 69, 10.

12. Cardinali, A.; Tursi, N.; Ligorio, A.; Giuffrida, M. G.; Napolitano, L.; Caliandro, R.; Sergio, L.; Venere, D. D.; Lattanzio, V.; Sonnante, G.; Plant Physiol. Biochem. 2011, 49, 395.

13. Devaiah, S. P.; Shetty, H. S.; Pestic. Biochem. Physiol. 2009, 94, 119.

14. Garda-Buffon, J.; Badiale-Furlong, E.; J. Braz. Chem. Soc. 2010, 21, 10.

15. Wang, J.; Cao, Y.; Baoguo, S.; Wang, C.; Mo, Y.; Ultrason. Sonochem. 2011, 18, 534.

16. Souza, M.; Mezadri, E. T.; Zimmerman, E.; Leaes, E. X.; Bassaco, M. M.; dal Prá, V.; Foletto, E.; Cancellier, A.; Terra, L. M.; Jahn, S. L.; Mazutti, M. A.; Ultrason. Sonochem. 2013, $20,89$.

17. Ciou, J.; Lin, H.; Chiang, P.; Wang, C.; Charles, A. L.; Food Chem. 2011, 27, 523.

Submitted: September 21, 2016

Published online: February 10, 2017

FAPERGS/CAPES has sponsored the publication of this article. 